\title{
Gut Microbiota Regulation and Their Implication in the Development of Neurodegenerative Disease
}

\author{
Peilin Sun ${ }^{1,2}$, Lei Su ${ }^{1,2} \mathbb{D}$, Hua Zhu ${ }^{1,2}$, Xue Li ${ }^{1,2}$, Yaxi Guo ${ }^{1,2}$, Xiaopeng Du ${ }^{1,2}$, Ling Zhang ${ }^{1,2}$ and Chuan Qin ${ }^{1,2, *}$ \\ 1 NHC Key Laboratory of Human Disease Comparative Medicine, Institute of Laboratory Animal Sciences, \\ Chinese Academy of Medical Sciences (CAMS), Beijing 100021, China; sunpeilin@cnilas.org (P.S.); \\ sulei@cnilas.org (L.S.); zhuh@cnilas.org (H.Z.); lixue@cnilas.org (X.L.); GYX409@163.com (Y.G.); \\ du_xiaopeng@163.com (X.D.); zhangling@cnilas.org (L.Z.) \\ 2 Beijing Engineering Research Center for Experimental Animal Models of Human Critical Diseases, \\ Chinese Academy of Medical Sciences (CAMS), Beijing 100021, China \\ * Correspondence: qinchuan@pumc.edu.cn; Tel.: +86-10-8777-8141
}

check for updates

Citation: Sun, P.; Su, L.; Zhu, H.; Li, X.; Guo, Y.; Du, X.; Zhang, L.; Qin, C. Gut Microbiota Regulation and Their Implication in the Development of Neurodegenerative Disease. Microorganisms 2021, 9, 2281. https://doi.org/10.3390/ microorganisms 9112281

Academic Editor: Anisha Wijeyesekera

Received: 5 September 2021

Accepted: 27 October 2021

Published: 2 November 2021

Publisher's Note: MDPI stays neutral with regard to jurisdictional claims in published maps and institutional affiliations.

Copyright: (C) 2021 by the authors. Licensee MDPI, Basel, Switzerland. This article is an open access article distributed under the terms and conditions of the Creative Commons Attribution (CC BY) license (https:// creativecommons.org/licenses/by/ $4.0 /)$.

\begin{abstract}
In recent years, human gut microbiota have become one of the most promising areas of microorganism research; meanwhile, the inter-relation between the gut microbiota and various human diseases is a primary focus. As is demonstrated by the accumulating evidence, the gastrointestinal tract and central nervous system interact through the gut-brain axis, which includes neuronal, immune-mediated and metabolite-mediated pathways. Additionally, recent progress from both preclinical and clinical studies indicated that gut microbiota play a pivotal role in gut-brain interactions, whereas the imbalance of the gut microbiota composition may be associated with the pathogenesis of neurological diseases (particularly neurodegenerative diseases), the underlying mechanism of which is insufficiently studied. This review aims to highlight the relationship between gut microbiota and neurodegenerative diseases, and to contribute to our understanding of the function of gut microbiota in neurodegeneration, as well as their relevant mechanisms. Furthermore, we also discuss the current application and future prospects of microbiota-associated therapy, including probiotics and fecal microbiota transplantation (FMT), potentially shedding new light on the research of neurodegeneration.
\end{abstract}

Keywords: gut microbiota; gut-brain axis; neurodegenerative diseases; Alzheimer's disease; Parkinson's disease; mechanism; metabolites; therapy; probiotics; fecal microbiota transplantation

\section{Introduction}

In recent years, human gut microbiota have become one of the most promising areas of microorganism research. To date, a large number of studies reveal that gut microbiota influence a wide range of human pathologies, including inflammatory bowel disease (IBD) [1-3]; irritable bowel syndrome (IBS) [4,5]; allergic [6-8], neurological [9-11], and metabolic diseases [12-14]; and psychiatric disorders [15], etc. The latest studies have begun to understand the mechanism by which gut microbiota affect the brain [16-18]. Additionally, the inter-communication between gut microbiota and the central nervous system has become increasingly evident.

The gut-brain axis is a two-way functional communication network between the intestine and the brain, which primarily includes neuroendocrine, neural, endocrine and immune signaling pathways [19,20] (Figure 1). The metabolites of intestinal microbiota, such as short-chain fatty acids, gamma aminobutyric acid (GABA), serotonin, kynurenines, norepinephrine, and histamine, etc., regulate a series of cerebral physiological processes in the brain through these pathways [21-24]. When the composition of the intestinal microbiome falls out of balance (i.e., dysbiosis), signals are sent to the brain that subsequently manifest as low-grade inflammation, heightened oxidative stress, disrupted energy 
metabolism and increased cellular degeneration [25], contributing to the pathological processes of assorted neurological diseases, particularly neurodegeneration [26,27]. On the other hand, aging in humans is reportedly also related to significant shifts in the composition of gut microbiota, and the loss of microbial diversity was also evident in the aging gut $[28,29]$. In addition, a striking alteration of microbiota composition was observed in the gastrointestinal tracts of elderly patients suffering from neurodegeneration [29]. Hence, researchers hypothesized that the alteration of human gut microbiota might well be one of the causes, or at least one of the contributing factors, of neurodegenerative diseases. In this review, we summarized the existing evidence regarding the influence of gut microbiota on neurodegenerative diseases and discussed the underlying mechanisms, relevant clinical implications, and potential applications.

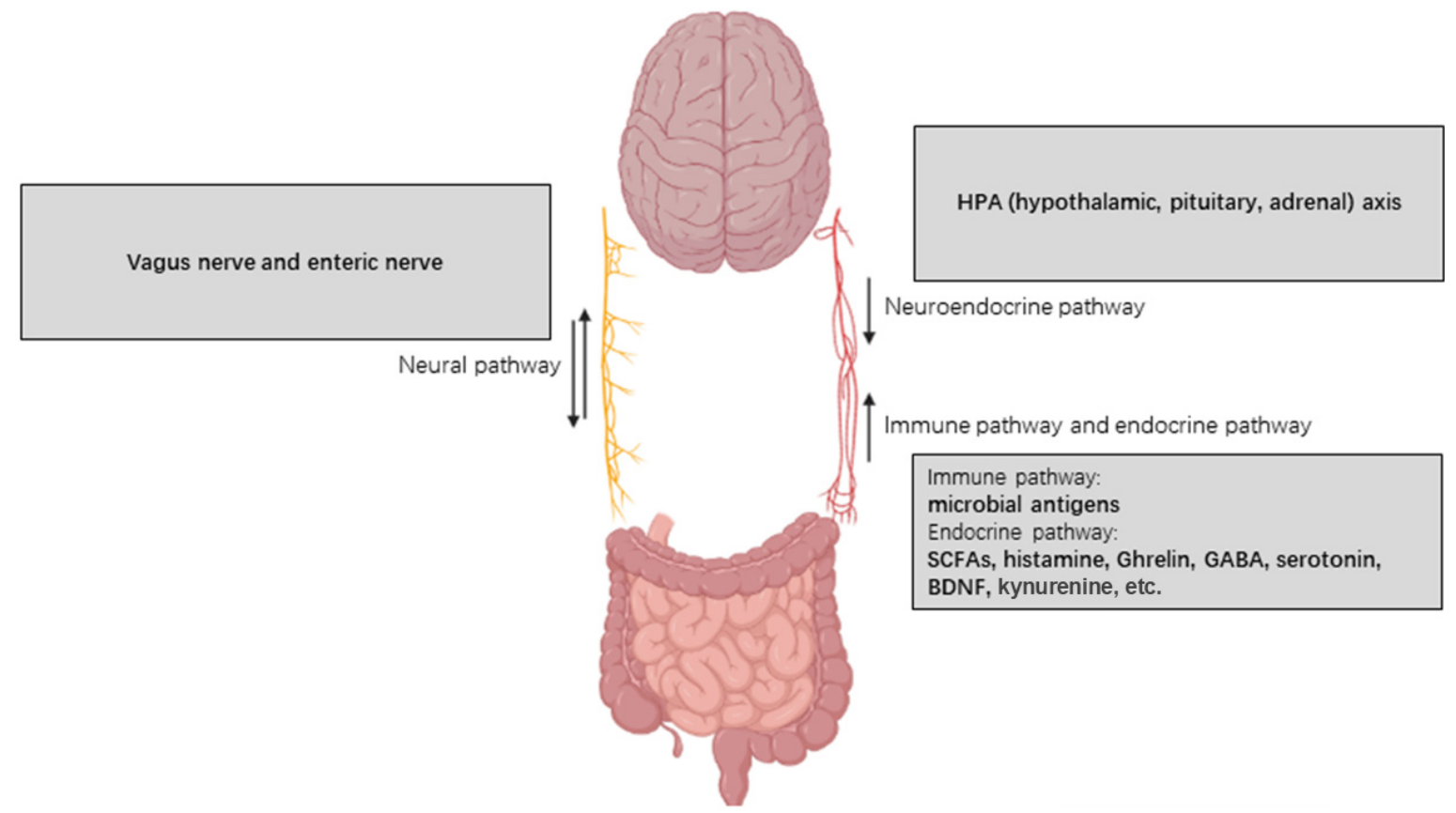

Figure 1. Pathways and participants of gut-brain axis. The gut-brain axis comprises primarily of a neural pathway, neuroendocrine pathway, immune pathway and endocrine pathway, of which the neural pathway functions through vagus and enteric nerves, whereas the latter three pathways function through blood circulation.

\section{Gut Microbiota and Neurodegenerative Diseases}

Neurodegenerative diseases are characterized by the progressive loss of neuronal function, resulting in eventual motor and/or cognitive function impairment. Currently, the prevalence of neurodegenerative disease is rapidly rising. Although genetic susceptibility is a major risk factor of neurodegenerative diseases, environmental factors throughout one's lifetime also exert a great influence on the onset, development and eventual severity of such diseases [30]. Currently, the increasing clinical and preclinical evidence suggests that changes in intestinal microorganisms may, to a certain extent, lead to an increased risk of neurodegeneration. Although the underlying mechanisms remain largely unknow, the hypothesis that gut microbes affect neurodegenerative diseases through the gut-brain axis is gaining increasing attention.

Alzheimer's disease (AD) is one of the most prevalent neurodegenerative diseases and is characterized by diminishing neurons and synapses, as well as a progressively declining cognitive function. Both environmental factors and genetics are considered to contribute to its etiology [31]. However, recent studies suggest that the alteration of gut microbiota composition is also related to the onset and development of $\mathrm{AD}$. In the works of Brandscheid et al. [32], it is suggested that the abundance of Firmicutes increased, whereas that of Bacteroidetes decreased in 9-month-old $5 \times$ FAD mice (experiment), as 
compared to 9-month-old WT mice (control). Yet, in a similar study, gut microbiota of similar-aged APP PS1 mice (about 8 months old) showed a decrease in both Firmicutes and Bacteroidetes when compared with WT mice [33], a result partially contradictive with the study of Brandscheid et al. Beyond animal experiments, Voet et al. [34] studied the composition of gut microbiota in AD patients by $16 \mathrm{~S}$ ribosomal RNA gene sequencing, and detected a reduced total abundance and diversity of microbiota in patient guts, as compared to healthy controls. In another human trial, an increased abundance of Escherichia and Shigella in the intestinal tract were found in patients with cognitive impairments and amyloid depositions, aa decreased abundance of Eubacterium rectale and Bacteroides fragilis was also observed, together with significantly increased inflammatory markers in circulation [35]. Furthermore, according to a recent comparative study, human AD patients had a decreased microbial diversity, compared to both healthy controls and patients with merely mild cognitive impairments (MCI). Furthermore, the abundance of Gammaproteobacteria, Enterobacteriales and Enterobacteriaceae all increased from the control group to the MCI group, and from the MCI group to the AD group. Additionally, a significant correlation was discovered between the clinical severity score of AD patients and the number of gut bacterial species with altered compositions [36]. All of this evidence suggests a significant alteration of gut microbiota in both animal models and patients of AD.

Gut microbiota secrete over 100 different types of metabolites, yet, to date, most of them still have undefined roles in the pathogenesis of AD. Butyric acid, propionic acid and other short-chain fatty acids were found to affect the activation of microglia and astrocytes and helped to reduce the inflammation and aggregation of $A \beta$ and tau in brain tissues $[37,38]$. Moreover, intestinal bacteria can also secrete a large number of lipopolysaccharide (LPS) and amyloid proteins. On one hand, these substances can directly enter the brain through the intestinal and blood-brain barriers. On the other hand, they can also induce a series of inflammatory reactions and increase the permeability of these barriers [39]. Additionally, the microbial amyloid protein produced by gut microbiota can also interact with the Toll-like receptor TLR2 to induce the activation of pro-inflammatory mediators such as interleukin (IL-17A, IL22), subsequently inducing an immune response and stimulating the production of the amyloid protein in the brain neurons [40].

Parkinson's disease (PD) is another prevalent example of neurodegeneration. The results of one study on gut microbiota dysbiosis found significantly elevated levels of indican (a dysbiosis marker) in PD patients [41]. In a large-scale cohort study that included 72 PD patients and an equivalent number of healthy controls, the results of the high resolution $16 S$ sequencing suggested that the amount of Prevotellaceae was reduced by $77.6 \%$ in PD patients. Notably, Prevotellaceae is a primary producer of mucin, which forms a barrier along the intestinal epithelium to defend against invading pathogens [42]. Moreover, as is suggested in a similar study, the abundance of bacteria that produce butyrate (a substance with an anti-inflammation effect), namely Roseburia and Faecalibacterium spp., significantly decreased in PD patients as compared to age-matched healthy controls. Intriguingly, the accumulating evidence linked PD with the accumulation of pathogenic $\alpha$-Syn in the gastrointestinal tract, implicating a potentially novel etiology.

Aside from AD and PD, less common forms of neurodegenerative disease include Huntington's disease, amyotrophic lateral sclerosis (ALS), and motor neuron disease, etc.

\section{Functions of Gut Microbiota}

\subsection{Enhanceing Intestinal Epithelial Barrier}

The epithelium barrier of the intestine is a primary defense mechanism that protects the body against environmental pathogens. The contents of the barrier include the epithelial junction adhesion complex and a layer of mucus with secretory $\operatorname{IgA}$, as well as antimicrobial peptides [43]. Once the barrier is breached, bacteria and other pathogens can reach the submucous layer and induce inflammation [44-46]. Certain non-pathogenic food-borne bacteria species are beneficial to the function of the intestinal barrier, of which the exact mechanisms remain insufficiently understood, though the increased expression 
of tight junction signaling-related genes induced by certain bacteria types might be one of the proper explanations $[47,48]$. As another possible protective mechanism, the association between the altered level of pro-inflammatory cytokine and intestinal tract permeability was also intensively elaborated [49,50]. Certain types of Lactobacillus enhanced the expression of mucins in human intestinal cell lines, yet the protective effect depended upon the adhesion of Lactobacillus on single-layered cells and this might not be the case of in vivo situations [51,52]. Additionally, there is also evidence indicating that the extractives of Lactobacillus alone increased the expression of MUC2 in HT29 cells, irrespective of the adhering mechanism [53]. Therefore, certain indigenous microbiota may have enhanced the intestinal epithelium barrier by increasing the production of intestinal mucus.

\subsection{Preventing Gastrointestinal Infection}

Indigenous microbiota in the intestinal tract is the first line of defense against invading exogenous pathogens [54]. Specifically, the beneficial microorganism species contribute to the prevention of intestinal infection through mechanisms such as altering the $\mathrm{pH}$ value of the intestinal microenvironment, secreting anti-bacterial substances, and directly competing for adhesion sites or nutrition on the epithelium surface [55-57]. In clinical scenarios, antibiotics-related diarrhea occurs mostly when the treatment with antibiotics starts to substantially disrupt the natural balance between the intestinal microbiota subpopulations and leads to the proliferation of harmful bacterial types (e.g., Clostridium difficile). Additionally, compared to the placebo control group, the administration of probiotics reduced the incidence rate of antibiotic-related diarrhea by $60 \%$ [58]. Additionally, Lactobacillus GG (a probiotic species) significantly shortened the disease course of infectious diarrhea in infants and children [59]. Both results suggested that certain types of gut microbiota might have played a substantial role in the systematic reaction against gut-mediated infection.

\subsection{Immunomodulatory Effects}

Gut microbiota can influence the progression of certain diseases through a modulatory effect on the host's immune responses [60]. Complex interactions can occur between gut microbiota and the surface of intestinal mucosa, which enhance the host's cellular immune reaction and manifest as the activation of immune cells (i.e., macrophages and antigenspecific cytotoxic T-lymphocytes) and the release of assorted cytokines [61]. Specifically, Lactobacillus salivarius and Bifidobacterium breve are considered important bacteria species that contribute to the stabilization of the immune system [62]. Other probiotic gut bacteria species, such as Lactobacillus plantarum, Bifidobacterium infantis, and Lactobacillus rhamnosus, might be efficacious in preventing and mitigating allergy and auto-immune diseases (e.g., irritable bowel syndrome and inflammatory bowel disease, etc.) [63-65].

\subsection{Nutritional Benefits}

Gut microbiota enrich the nutrient sources of the host by synthesizing certain vitamins and assorted biologically active metabolites (e.g., short-chain fatty acids, SCFAs), most of which can be directly or indirectly utilized by the host system. Previous animal experiments reached this conclusion based on the fact that a number of vitamin types found in the intestines of regular mice could not be found in the intestines of germ-free mice $[66,67]$. Upon investigation, these particular vitamins are synthesized mostly by several specific bacterial types in the gut, including Propionibacterium, Fusobacterium, Bacteroides, and Eubacterium $[67,68]$. On the other hand, ingesting yogurt that contains Lactobacillus bulgaricus, Lactobacillus delbrueckii, or Lactobacillus acidophilus can reportedly reduce the incidence of lactose intolerance, presumably with the enzyme lactase within the bacteria per se [69]. Nevertheless, it is worth mentioning that the primary metabolic function of colonic microbiota is the fermentation of nondigestible carbohydrates, of which SCFA is one of the major end products. SCFAs have trophic functions that are fundamental in the life cycles of the intestinal epithelium [70]. 


\section{Underlying Mechanisms of the Influence of Gut Microbiota on Neurodegeneration}

The notion of maintaining gut microbiome homeostasis for the health of neurological system is attracting increasing attention. Here, we discuss the mechanisms through which gut microbiota exert an influence, both direct or indirect, on the central nervous system (Figure 2).

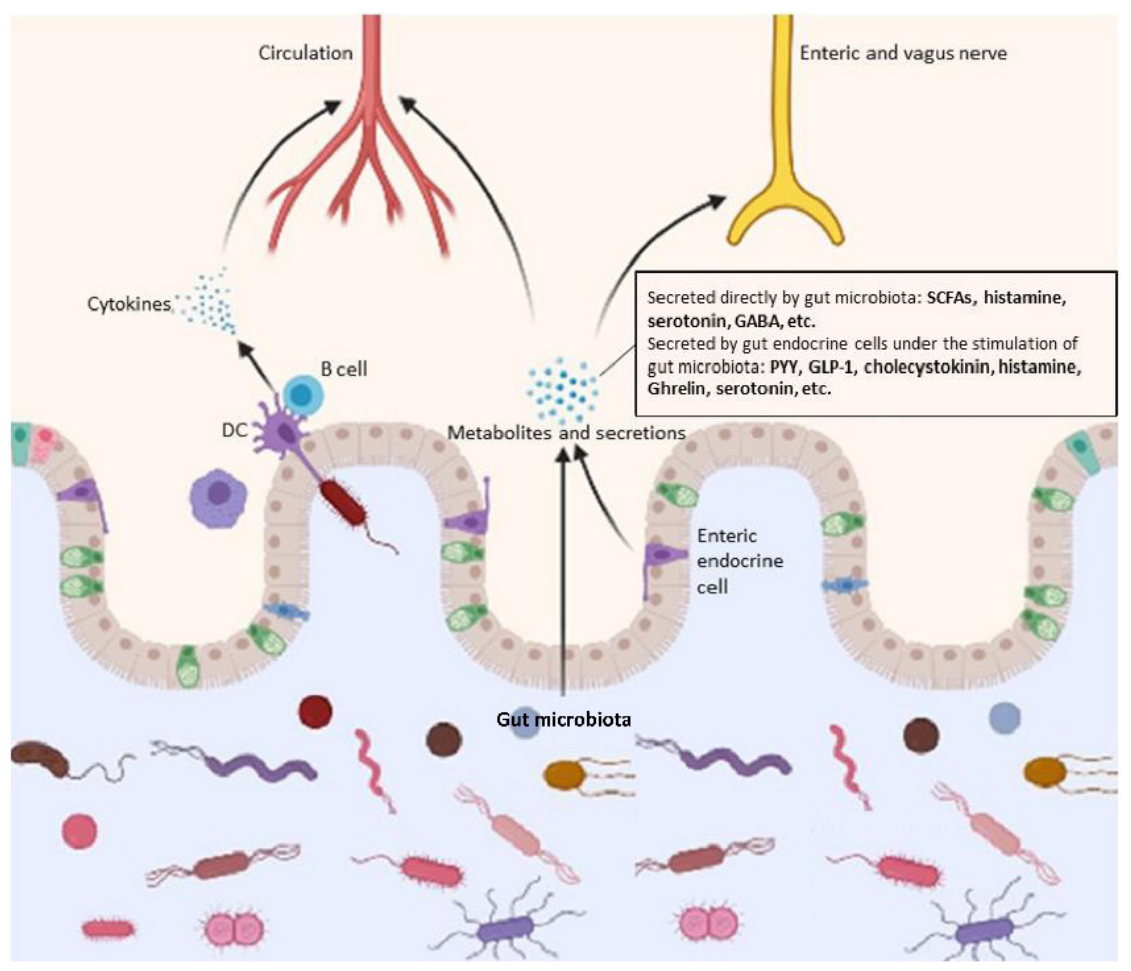

Figure 2. Mechanisms through which gut microbiota exert an influence on neurodegenerative diseases. Shown in the figure are the structural bases (i.e., blood circulation, and enteric and vagus nerves) and major events during the process.

\subsection{Production of Assorted Functional Metabolites}

\subsubsection{Tryptophan Metabolites}

The tryptophan (TRP)-kynurenine (KYN) pathway and its metabolites were observed to play an important role in neuroinflammation [71,72]. Tryptophan is one of the eight essential amino acids in the human body and can be attained from a dietary protein only; it is the only amino acid with an indole structure. The level of free tryptophan is determined by both food intake and the activity of three tryptophan metabolic pathways. Of the three, the indole pathways are directly regulated whereas the kynurenine pathway and serotonin pathway are indirectly regulated by gut microbiota. Overall, a rather small fraction of free tryptophan (TRP) is utilized for the synthesis of proteins and the production of neurotransmitters, e.g., serotonin 5-HT)/neuromodulators such as tryptamine, whereas over $95 \%$ of free tryptophan is the degradation substrate of the TRP-KYN pathway [73-75], where various bioactive metabolites such as neuroprotective antioxidants and neuroprotectants, toxic oxidants, and neurotoxins, as well as immunomodulators, are synthesized [71]. Notably, two key intermediate metabolites of the TRP-KYN pathway are quinolinic acid (QA) and kynurenine uric acid (KA). QA can induce neurodegeneration through NMDAmediated excitotoxicity [76], while, as an endogenous NMDA receptor antagonist, KA can regulate the neurotoxic effect of QA and bears neuroprotective functions [77]. According to several studies, the TRP-KYN pathway is crucial for neurodegeneration as well as severe brain injury [78]. Being the rate-limiting enzymes of the pathway, hepatic tryptophan 2,3-dioxygenase (TDO) and extra-hepatic indoleamine 2,3-dioxygenase (IDO) also activate the TRP-KYN pathway, producing neuroactive metabolites such as QA and 
KA. Furthermore, an indicator of IDO/TDO activity is the kynurenine per tryptophan quotient (KYN/TRP) ratio. The evidence suggests that the increase in the KYN/TRP ratio is directly proportional to the severity of the impairment on cognitive function [79]. Additionally, there is also evidence that gut microbiota can directly influence the activities of key enzymes in the TRP-KYN pathway. It is worth mentioning that the activity of IDO is decreased in the intestinal tract of germ-free mice, yet it could be restored to normal by colonizing microorganisms in the intestinal tract immediately after weaning $[80,81]$.

In recent years, the accumulating studies have shown that the serum concentration of kynurenine (KYN) and 3-hydroxykynurenine (3-HK), which are intermediate metabolites of TRP-KYN pathway, increased significantly in AD animal models; whereas, the concentrations of TRP and KA showed a downward trend, which was closely related to cognitive function impairment [82]. In Parkinson's disease, the concentration of 3-HK in the frontal cortex, putamen and substantia nigra increased significantly, while the concentration of KA decreased [83]. On the other hand, the TRP-KYN pathway metabolites were also considered to be related to the pathological process of Huntington's disease. Additionally, the concentrations of QA and 3-HK increased in both the neostriatum and cortex of Huntington patients and transgenic mice, compared to control group [84]. Interestingly though, the probiotic treatment alters the kynurenine levels [85]. Additionally, other studies have shown that as an inhibitory neurotransmitter, serotonin can reduce the formation of the $A \beta$ plaque and regulate cognitive function [86]. It is worth noting that about $90 \%$ of serotonin is produced in the chromaffin cells of the gastrointestinal tract. Additionally, Escherichia coli and Enterococcus, which are common bacteria in the intestine, can also produce serotonin [87]. Therefore, gut microbiota may affect the function of the central nervous system by controlling the production of serotonin.

\subsubsection{Short-Chain Fatty Acids}

SCFAs are one of the metabolic end products of gut microbiota. SCFAs are primarily composed of butyrate, propionate, and acetate, which are synthetized from undigested food carbohydrates and proteins [88]. The specific types of SCFAs produced by gut microbiota depend primarily on the relative amount of microbiota subgroups, i.e., microbiota composition. For example, microbes in the Firmicutes predominantly produce butyrate whereas Bifidobacteria spp. mostly synthetize lactate and acetate [89]. Regarding the functions of SCFAs, these small molecules participate in the cellular signaling of the epithelium via FFAR2 (G-protein-coupled free fatty acid receptors 2) and FFAR3 in the gastrointestinal tract. Meanwhile, SCFAs can also enter the systematic circulation passively or actively, exerting a rather broad range of physiological effects [90], including participation in the metabolism of glucose and lipids [91-93].

SCFA can affect the function and development of the nervous system. For example, SCFA was proved to aggravate the motor symptoms in sterile PD mice [94], yet they improved the recovery of experimental stroke mice [95]. Acetate is shown to be able to penetrate the blood-brain barrier and reduce eating behavior in mice $[96,97]$. Butyric acid is a multi-functional molecule, which plays a beneficial neuroprotective role and improves the health of the brain. In addition to being an important substrate for energy production, butyric acid can also increase the mitochondrial respiration rate and ATP production, inhibit histone deacetylase, and affect the function of many genes and a large number of cellular proteins [98]. In addition, short chain fatty acids can stimulate the release of neuropeptides by binding to homologous receptors such asGPR43, GPR41, peptide YY (PYY) and GLP-1 (Glucagon-like peptide 1), which play a special role in intestinal endocrine signaling. Once released, these peptides affect the regulation of energy homeostasis by activating intestinal and primary afferent vagal pathways [99].

\subsubsection{Histamine}

In the intestinal tract, histamine is produced primarily by enterochromaffin (EC) cells. It plays significant roles in assorted physiological activities such as cell proliferation, 
wound healing, allergic reaction, immune cell regulation, etc., and functions as one of the most important neurotransmitters in the brain [100]. Large amounts of histamine receptors are found on the neurons in the hippocampus, thalamus, striatum, substantia nigra, and other brain regions, implicating their wide-ranging effects in the entire central nervous system. Recently, histamine was proposed to be a potential drug for the treatment of neurodegenerative diseases, specifically for MS and AD [101].

Histamine was recently found to be the metabolic product of intestinal microbiota. Lactococcus, Lactobacillus, Streptococcus, and Pediococcus all carry the gene of histidine decarboxylase, and thus can produce histamine [102]. Lactobacillus reuteri, previously considered as immune, modulatory, probiotic bacteria, were found to be able to transform the foodborne L-histidine into histamine [103]. As with neurodegenerative disorders, the increase in histamine levels is found to be associated with AD, and is believed to increase the level of nitrogen oxide, which is a stimulating factor of neural inflammation [104]. Furthermore, there are also studies that report the histaminergic signaling deficiency in vascular dementia rats [105]. In other words, histamine has a broad-ranging effect on the development of neurodegenerative disorders. Therefore, the regulation of its metabolism by gut microbiota can be a novel and potentially effective therapeutic approach for neurodegeneration.

\subsubsection{Ghrelin}

Ghrelin is a neuropeptide that is generated in the gastrointestinal tract and transmits satiety signals; it can also be found in the central nervous system. Ghrelin is secreted primarily when the stomach is empty, after which it reaches the brain through blood circulation and generates the feeling of hunger. Moreover, ghrelin acts as a key modulating factor in multiple metabolism processes, including energy homeostasis, inflammation, and neuro-modulation [106,107]. Notably, ghrelin is proven to be neuro-protective in both $\mathrm{AD}$ and PD [108]. The evidence suggests that the expression of ghrelin is reduced in the brains of AD patients, indicating a critical role in the pathological process of AD [109]. In $\mathrm{PD}$, the activation of the ghrelin receptors of substantia nigra neurons stimulates the expression of tyrosine hydroxylase, promoting the synthesis of dopamine. Furthermore, it was demonstrated that, upon administering Bifidobacterium spp., the secretion of ghrelin in the human system was significantly decreased [110]. In brief, ghrelin produced from gut microbiota has a significant role in maintaining the regular function of the brain and is a promising target for the treatment of neurodegeneration.

\subsubsection{Neuro-Metabolites}

A large number of neuro-metabolites are secreted directly by gut microbiota, or by secretory epithelial cells due to the stimulation of microbiota. These neuro-metabolites include neurotransmitters that act directly on the central nervous system (CNS), signaling cascades or other signaling pathways and exerting direct or indirect influences on the regular function of the CNS [111,112]. For example, Lactobacillus and Bifidobacterium strains can produce large amounts of GABA when a suitable substrate is present [113]. Gutderived neuro-metabolites communicate with the central nervous system by stimulating the local afferent vagal fibers or through distal endocrine action. The variations in the level of neurotransmitters lead to changes in behavior, such as the heightened activity of spontaneous motor nerves due to elevated levels of noradrenaline, dopamine, and serotonin in the striatum [113]. Additionally, this phenomenon is significant in the management of neurodegenerative diseases where there is, more often than not, a dysregulation of neurotransmitter production that ultimately contributes to disease progression.

\subsection{Microbial-Associated Molecular Patterns (MAMPs) and Immune Responses}

Microbial-associated molecular patterns (MAMPs) are highly conservative components of assorted microbials [114]. They are the essential components that compose microbial pathogenicity [115]. MAMPs bind to the pattern recognition receptor (PRR) in the immune cells and trigger the secretion of inflammatory cytokines. These cytokines 
can affect the brain indirectly through the peripheral vagus nerve, or directly through the permeable areas of the blood-brain barrier [116]. Peptidoglycan and LPS are two primary constituents of MAMP [117]. Peptidoglycans are structural components of almost all bacterial cell walls and can be transferred to the developing brain, exerting an influence on gene expression and social behavior [118]. LPS, another ubiquitous surface molecule of Gram-negative bacteria, has been shown to induce cognitive impairment in mice upon injection [119], and also reportedly affected the development of the fetal brain [120,121]. The existence, structure, and immunomodulatory activity of MAMPs vary with different bacterial species. Therefore, gut microbiota may affect the host's exposure level and response to specific MAMPs by restoring normal bacterial flora constitution, and thus inhibit neuroinflammation and regulate the host's overall health status and behavior changes.

\subsection{Vagus Nerve}

The vagus nerve, or the tenth cranial nerve, transmits sensory information between the peripheral and central nervous systems, and functions as a direct connection between the gut and the brain [122,123]. Multiple studies have shown that the primary afferent fibers of the vagus nerve mediate the communication between gut microbiota and the central nervous system $[124,125]$. The pathogens and certain indigenous microbiota in the gut affect brain function and behavior by activating vagus nerve neurons, and thus altering neural activity [122,126,127]. These responses all disappeared after the severance of the vagus nerve. However, the specific bacterial metabolites that mediate these effects remain undefined. Exploring the role of the vagal afferent pathway in regulating the crosstalk between gut microbiota and the brain may pave the way for microbiota-related therapy to be tested in the treatment of neurological diseases.

\subsection{Inhibition on Harmful Gut Microorganisms}

Gut microbiota can protect host systems from possible infections by directly inhibiting intestinal pathogens. Generally, such inhibition effects are realized primarily through the production of anti-bacterial substances such as hydrogen peroxide, bacteriocins, and organic acids. Furthermore, certain native bacterial species exert modulatory effects on the pathogenicity of intestinal pathogens, mechanisms of which include anti-colonization $\mathrm{n}$ and toxin neutralization, etc. Furthermore, gut microbiota's competition for nutritional substances also exerts a suppressive effect on harmful gut microorganisms [128,129].

\subsection{Others}

Bacteria is occasionally capable of passing through the blood-brain barrier, or the blood-cerebrospinal fluid barrier, to enter the central nervous system, the mechanisms of which include trans-cellular infiltration, paracellular entering, or via the infected leukocytes [130]. Branton et al. [131] detected the existence of bacteria in the brain tissue of multiple sclerosis (MS) patients and discovered that Proteobacteria were the dominant flora in the cerebral white matter of female MS patients, a phenomenon that is reportedly associated with the expression of inflammation-related genes in patients' brains. Furthermore, the research confirmed a strong interaction between the bacterial presence in the brain and host responses involving NF $\kappa$ B-related signaling, a pivotal pathway in neuroinflammation and MS pathogenesis, in demyelinating lesions [132]. Studies also found that Porphyromonas gingivalis, a primary pathogen of chronic periodontitis, existed in the brain tissue of patients with Alzheimer's disease. Additionally, Porphyromonas gingivalis was also associated with impaired spatial/episodic memory in AD [133]. In related animal experiments, these pathogenic bacteria "invade" the brain after an oral infection, leading to an increase in the amyloid beta protein [134]. However, it is still not clear whether the gut microbes can enter and colonize the brain simply through blood circulation, as the evidence for this is very limited. In a study presented at the 2018 annual meeting of the American Society of Neuroscience, 34 brain samples of healthy people and schizophrenic patients were analyzed by an electron microscope, and bacteria were found 
in all samples. In the same study, bacteria were also found in the brains of healthy mice but not in sterile mice. These bacteria mainly came from three common intestinal bacteria phylum (Firmicutes, Proteobacteria, and Bacteroidetes), which tended to gather in the astrocytes and neuron axons adjacent to the blood-brain barrier and did not seem to have caused the inflammation of the mouse brain tissues [135]. After a thorough inspection of these results, the possibility of experimental contamination is yet to be excluded, and further studies are still needed to support these preliminary findings.

\section{Microbiota-Associated Therapy in Application}

Two primary forms of microbiota-associated therapy in the current applications of neurological diseases are probiotics therapy and fecal microbiota transplantation [136].

\subsection{Probiotics Therapy}

As demonstrated by a number of animal experiments, the administration of beneficial microorganisms (i.e., probiotics) could be a promising method to prevent and treat neurodegenerative diseases. Particularly, the probiotic preparations for oral administration, whether for single-strain or multi-strain microorganisms, proved to be a successful therapeutic strategy. For example, Probiotic-4 is a preparation containing Bifidobacterium lactis, Lactobacillus casei, Bifidobacterium bifidum, and Lactobacillus acidophilus. It functions to significantly inhibit Proteobacteria (phylum), Pseudomonas (genus) and the Lachnospiraceae_NK4A136_group (genus); meanwhile, it significantly reduces the ratio of Firmicutes to Bacteroidetes and improves the cognitive function of aged SAMP8 mice through the inhibition of the NF- $\mathrm{B}$ signaling pathway and the inflammatory reactions, which are mediated by TLR4 and RIG-I [137]. In another study, a probiotic mixture containing Lactobacillus acidophilus, Lactobacillus fermentum, Bifidobacterium lactis, and Bifidobacterium longum was given to rats injected with $\mathrm{A} \beta$ for 8 weeks. The results indicated an improved spatial memory, learning impairments and a reduced oxidative stress through the alteration of the gut microbiota composition [138]. Recently, SLAB51, a formulation composed of Lactobacillus and Bifidobacterium, was reported to modulate the gut microbiota of 3xTG AD mice, increasing the relative abundance of Bifidobacterium spp. while reducing the relative abundance of Campylobacter. The study concluded that these alterations of microbiota composition, together with the abundance of SCFA in the intestine and the increased level of the neuroprotective, intestinal peptide hormone in plasma, could alleviate the decline of cognitive ability by reducing the A $\beta$ aggregate and, subsequently, brain damage [139]. The combination of Lactobacillus helveticus R0052 and Bifidobacterium longum R0175 could significantly decrease the levels of pro-inflammatory cytokines in the serum and hippocampus that were induced by LPS, reducing the apoptosis of hippocampal cells, and attenuating the adverse effects of LPS on memory by expressing BDNF proteins $[140,141]$. In another study, ddY mice injected with A $\beta$ were treated with $1 \times 10^{9}$ CFU Bifidobacterium breve A1, which improved both the behavior and memory of the mice, whilst inhibiting the expression of the immune response genes and inflammation-related genes in the hippocampus [142]. Another study suggested that the treatment of Lactobacillus plantarum MTCC1325 for 60 days in a D-galactose-induced rat model not only improved cognitive impairment, but also restored the level of $\mathrm{ACh}$ and the features of histopathology to the control levels [143]. Wang et al. [144] and Liang et al. [145] found that Lactobacillus fermentum NS9 and Lactobacillus helveticus NS8 alleviated ampicillin-induced spatial memory impairment and improved the spatial memory of chronic restraint stress. Additionally, a recent study showed that exercise combined with a probiotics mixture could reduce $A \beta$ plaque in the hippocampus, improving cognitive ability and, ultimately, slowing down the development of AD in an APP/PS1 mouse model [146]. Zhang et al. reported that, after a treatment with $2 \%$ butyrate (a natural bacterial product that helps restore the homeostasis of gut microbiota), the gut microbiota balance and intestinal epithelial barrier integrity of G93A mice was reinstated. Additionally, aside from improving the central and 
peripheral symptoms of the disease, G93A mice demonstrated a prolonged survival time and reduced body weight [147].

Similar to probiotics applications in humans, Lactobacillus and Bifidobacterium are widely used in probiotic preparations in clinical settings, as bacteria members of these two categories are widely used to promote human health and are rated as GRAS (generally regulated as safe) for human consumption [148]. In the study by Akbari et al., patients with AD were fed with Lactobacillus acidophilus, Lactobacillus casei, Bifidobacterium bifidum, and Lactobacillus fermentum for 12 weeks ( $200 \mathrm{~mL} / \mathrm{D})$. Compared with the control group, the probiotics treatment had no significant effect on oxidative stress, inflammation, fasting, blood glucose, and biomarkers of lipid distribution, but had a positive effect on the cognitive function and insulin metabolism of AD patients [149]. However, as reported by Agahi A et al. [150], after AD patients were given Lactobacillus fermentum, Lactobacillus plantarum, and Bifidobacterium lactis, or Lactobacillus acidophilus, Bifidobacterium bifidum, and Bifidobacterium longum $\left(3 \times 10^{9} \mathrm{CFU}\right)$, respectively, for 12 weeks, no difference was observed regarding the cognitive test scores between the two groups, and the serum inflammatory factors (IL-6, IL-10 and TNF- $\alpha$ ), glutathione (GSH), malondialdehyde (MDA), and itric oxide (NO) were not significantly changed either, suggesting that probiotics could not effectively improve the cognitive and biochemical indicators of patients with severe AD. Therefore, in addition to the formulation and dosage of probiotics, the severity of the disease per se also plays a critical role in causing the beneficial effect of probiotic intervention in AD patients. According to Kobayashi Y et al., after taking a Bifidobacterium breve A1 capsule for 12 weeks, the scores of a Mini Mental State Examination (MMSE) and a Repeatable Battery for the Assessment of Neuropsychological Status (RBANS) both changed significantly, while the changes in the levels of serum lipid, inflammation, and oxidative stress markers were not significant, suggesting that Bifidobacterium breve A1 was safe and could improve the impaired cognitive function (i.e., memory impairment) of the elderly [151]. Furthermore, the consumption (for 4 weeks) of a fermented milk containing multiple probiotic strains and probiotic fibers was shown to improve PD complications, particularly the symptom of constipation [152].

The safe use of probiotics was strongly supported by various studies demonstrating how endogenous microorganisms played important roles in our personal health, particularly regarding neurodegeneration (Table 1 ). These studies showed that positive results could be obtained when specific microbial strains were administered as probiotics.

Table 1. Probiotics administration influences gut microbiota and the gut-brain axis: evidence from clinical and pre-clinical studies.

\begin{tabular}{|c|c|c|c|c|}
\hline Probiotic Used & Subjects/Samples & Function & Diseases Involved & Reference \\
\hline $\begin{array}{c}\text { Lactobacillus plantarum } \\
\text { MTCC1325 }\end{array}$ & $\begin{array}{l}\text { D-galactose-induced AD } \\
\text { albino rats ( } 3 \text { months old) }\end{array}$ & $\begin{array}{c}\text { Reduced formation of } \mathrm{A} \beta \text { plaques, restored } \\
\text { Acetylcholine leve, improved } \\
\text { cognitive function }\end{array}$ & $\mathrm{AD}$ & [143] \\
\hline $\begin{array}{c}\text { Bifidobacterium breve } \\
\text { strain A1 }\end{array}$ & $\begin{array}{l}\text { A } \beta \text {-injected male ddY } \\
\text { mice (10 weeks old) }\end{array}$ & $\begin{array}{l}\text { Produced SCAFs, regulated immune } \\
\text { responses and inhibited neural inflammation, } \\
\text { improved cognitive function }\end{array}$ & $\mathrm{AD}$ & {$[142]$} \\
\hline $\begin{array}{c}\text { Lactobacillus fermentum } \\
\text { NS9 }\end{array}$ & $\begin{array}{l}\text { Ampicillin induced male } \\
\text { SD rats }\end{array}$ & $\begin{array}{l}\text { Restored normal composition of gut } \\
\text { microbiota, and reversed antibiotics-induced } \\
\text { anxiety behavior and spatial memory defects }\end{array}$ & $\mathrm{AD}$ & [144] \\
\hline \multirow[t]{2}{*}{ Lactobacillus helveticus NS8 } & $\begin{array}{l}\text { Adult male SD rats to } \\
\text { construct depression-like } \\
\text { rat model of chronic } \\
\text { restraint stress }\end{array}$ & $\begin{array}{l}\text { Restored level of 5-HT and BDNF in } \\
\text { hippocampus body, regulated } \\
\text { inflammation responses }\end{array}$ & \multirow[t]{2}{*}{$\begin{array}{l}\text { AD, anxiety, } \\
\text { depression }\end{array}$} & [145] \\
\hline & $\begin{array}{l}\text { Male SD rats to construct } \\
\text { rat model of } \\
\text { hyperammonemia }\end{array}$ & $\begin{array}{c}\text { Reduced the level of inflammation biomarkers, } \\
\text { decreased 5-HT metabolism, restored } \\
\text { cognitive function, improved } \\
\text { anxiety-like behavior }\end{array}$ & & {$[153]$} \\
\hline $\begin{array}{l}\text { Bifidobacterium breve } \\
\text { strain A1 }\end{array}$ & $\begin{array}{l}\text { Elderly with } \\
\text { memory dysfunction }\end{array}$ & Improvement with cognitive function & $\mathrm{AD}$ & {$[150]$} \\
\hline $\begin{array}{l}\text { Bifidobacterium infantis } \\
35624\end{array}$ & SD rats & $\begin{array}{c}\text { Modulated HPA stress response, reduced } \\
\text { pro-inflammation immune response, increased } \\
\text { level of } 5 \text {-HTP }\end{array}$ & Depression & {$[85]$} \\
\hline
\end{tabular}


Table 1. Cont.

\begin{tabular}{|c|c|c|c|c|}
\hline Probiotic Used & Subjects/Samples & Function & Diseases Involved & Reference \\
\hline $\begin{array}{l}\text { Lactobacillus reuteri } \\
\text { ATCC } 23272\end{array}$ & $\begin{array}{l}\text { C57BL } / 6 \text { and BALB /c } \\
\text { mice }\end{array}$ & $\begin{array}{l}\text { Inhibited metabolism of } \\
\text { tryptophan/kynurenine }\end{array}$ & Depression & [154] \\
\hline $\begin{array}{l}\text { Lactobacillus reuteri } \\
\text { ATCC-PTA- } 6475\end{array}$ & ASD mice & $\begin{array}{l}\text { Upregulated level of oxytocin in brain, } \\
\text { regulated plasticity of neurons }\end{array}$ & ASD & [122] \\
\hline $\begin{array}{l}\text { Bifidobacterium longum } \\
\text { NCC3001 }\end{array}$ & AKR mice & $\begin{array}{c}\text { Upregulated level of brain-derived } \\
\text { neurotrophic factor, regulated plasticity } \\
\text { of neurons }\end{array}$ & Anxiety & [126] \\
\hline $\begin{array}{c}\text { Lactobacillus helveticus } \\
\text { R0052 and Bifidobacterium } \\
\text { longum R0175 }\end{array}$ & LPS-induced rats & $\begin{array}{l}\text { Reduced level of pro-inflammatory cytokines, } \\
\text { reduced the apoptosis of hippocampal cells, } \\
\text { improved memory }\end{array}$ & $\mathrm{AD}$ & {$[140,141]$} \\
\hline Lactobacillus rhamnosus & & & & \\
\hline $\begin{array}{l}\text { GG(L-GG), Bifidobacterium } \\
\text { animalis lactis(BB-12), } \\
\text { and Lactobacillus } \\
\text { acidophilus (LA-5) }\end{array}$ & MPTP-induced mice & $\begin{array}{l}\text { Butyrate, prevented the loss of dopaminergic } \\
\text { neurons by upregulating neurotrophic factors } \\
\text { and inhibiting the expression of Mao B }\end{array}$ & PD & [155] \\
\hline $\begin{array}{l}\text { DW2009: a mixture of } \\
\text { fermented soybean } \\
\text { powder and L. plantarum } \\
\text { C29 freeze-dried powder. }\end{array}$ & MCI patients & $\begin{array}{l}\text { Increased the abundance of Lactobacilli, } \\
\text { increased serum BDNF level, improved } \\
\text { cognitive function }\end{array}$ & $\mathrm{AD}$ & [156] \\
\hline
\end{tabular}

AD Alzheimer's disease, PD Parkinson's disease, ASD Autism Spectrum Disorder, SCAFs short-chain fatty acids, 5-HT 5-hydroxytryptamine, 5-HTP 5-hydroxytryptophan, BDNF brain-derived neurotrophic factor, HPA The hypothalamic-pituitaryadrenal axis, LPS lipopolysaccharides, MPTP Pyridine,1,2,3,6-tetrahydro-1-methyl-4-phenyl-, Mao B monoamine oxidase B, MCI mild cognitive impairment.

\subsection{Fecal Microbiota Transplantation (FMT)}

FMT refers to the transplantation of feces containing gut microbiota from healthy donors to recipients with dysbacteriosis, by means of an enema or nasogastric, nasointestinal, or endoscopic approaches, aiming to restore the normal diversity and functionality of the gut microbiome $[157,158]$. This method is currently considered an effective treatment for the recurrent infection of Clostridium difficile [159]. With the bidirectional signal interaction of the gut-brain axis, FMT is also considered as a potential treatment for certain extraintestinal diseases, including neurodegenerative diseases. Dodiya et al. [160] found that the transplantation of fecal microbiota from APP/PS1-21 male mice into age-matched antibiotic-treated APP/PS1-21 male mice could restore the normal intestinal microbiome, and partially reverse $A \beta$ pathology and microglia morphology. Another study found that, compared with healthy control mice, mice transplanted with feces from patients with AD had a poorer cognitive function and fewer fecal metabolites, which were associated with the nervous system (e.g., GABA, taurine, and valine) [161]. Admittedly, there are currently few studies reporting the effect of FMT on neurological diseases in human subjects, and safety is still a major issue in translating FMT research into human trials. As with existing or ongoing human studies, fecal donors and samples of FMT are subjected to examinations for potentially pathogenic bacteria, viruses, and parasites, etc. [162]. Nevertheless, the exact and optimal microbial composition of the samples to be transplanted is still under investigation, which, as far as human trials are concerned, not only raises potential safety concerns, but also leads to problems with the interpretation of results.

\subsection{Future Prospect}

Neurodegenerative diseases have complex conditions that usually involve cognitive, motor, and systemic dysfunctions. Both genetic and environmental factors are considered relevant to their pathogeneses, among which gut microbiota may also be a potential influencing factor. The manipulation of intestinal microbiota by FMT may affect the symptoms or progression of diseases through immune, endocrine, metabolic, and/or neural pathways mediated by intestinal microorganisms, thus constituting, despite limited evidence, a potential treatment option for a variety of neurological diseases. Future studies should carefully weigh up the potential benefits and risks of microbiota-related interventions and put safety first regarding human subjects. Compared with FMT, probiotic therapy is more selective and targeted. Probiotics can directly or indirectly act against or 
destroy other harmful microorganisms in the intestine. At the same time, it is necessary to ensure that these probiotics maintain a normal activity and metabolism in the host body. Probiotics are often exposed to gastric juice and bile before they reach the intestinal tract. These acidic environments lead to the death of most bacteria before they even reach the small intestine or colon. Therefore, effective measures should be taken to ensure the effective activity of probiotics. In summary, a better understanding of the gut-brain axis is expected to accelerate the development of probiotic therapy, as well as the prevention of and intervention in neurodegenerative diseases.

\section{Conclusions}

Gut microbiota are implicated in the pathogenesis of neurodegenerative diseases. Metabolites produced by intestinal microorganisms, as chemical messengers, mediate the interaction between microbiota and the host. Of note, some of these metabolites are proven to affect the outcome of neurodegeneration. However, there is still much to explore regarding the functions of the metabolites of gut microbiota. Our ultimate goal with this review was to summarize the existing evidence connecting gut microbiota with neurodegenerative diseases, which may potentially facilitate researchers in the field of neurodegeneration who are exploring new possibilities in the largely uncharted territory of gut microbiota. However, one particular limitation of this review is its narrow scope with an intensive focus on AD and PD. The application of different animal models and an omics analysis may help us to further discover and decipher the relationship between intestinal microorganisms, metabolites, and neurodegenerative diseases. The current pre-clinical studies and human clinical trials of intestinal microbiota are still in the early stages, but many studies have pointed out the potentially significant role of various microbiota-related treatments (e.g., probiotics and FMT) in changing the composition of gut microbiota. Further studies on the relationship between intestinal microorganisms and certain important neurometabolites will hopefully provide new concepts and methodologies for the prevention of and intervention in neurodegenerative diseases.

Author Contributions: Conceptualization, C.Q.; formal analysis, P.S.; investigation, P.S.; resources, L.S.; data curation, P.S.; writing—original draft preparation, P.S., L.S.; writing-review and editing, L.S., H.Z., X.L.; visualization, Y.G., X.D.; supervision, L.Z.; project administration, C.Q.; funding acquisition, C.Q. All authors have read and agreed to the published version of the manuscript.

Funding: This research was funded by National Natural Science Foundation of China, grant number 81941012, 31970510, and by CAMS Innovation Fund for Medical Sciences (CIFMS), grant number 2017-12M-2-005, 2016-I2M-2-006.

Institutional Review Board Statement: Not applicable.

Informed Consent Statement: Not applicable.

Data Availability Statement: Not applicable.

Conflicts of Interest: The authors declare no conflict of interest.

\section{References}

1. Kudelka, M.R.; Hinrichs, B.H.; Darby, T.; Moreno, C.S.; Nishio, H.; Cutler, C.E.; Wang, J.; Wu, H.; Zeng, J.; Wang, Y.; et al. Cosmc is an X-linked inflammatory bowel disease risk gene that spatially regulates gut microbiota and contributes to sex-specific risk. Proc. Nat. Acad. Sci USA 2016, 113, 14787-14792. [CrossRef]

2. Mar, J.S.; LaMere, B.J.; Lin, D.L.; Levan, S.; Nazareth, M.; Mahadevan, U.; Lynch, S.V. Disease Severity and Immune Activity Relate to Distinct Interkingdom Gut Microbiome States in Ethnically Distinct Ulcerative Colitis Patients. mBio 2016, 7, e01072-16. [CrossRef] [PubMed]

3. Schirmer, M.; Franzosa, E.A.; Lloyd-Price, J.; McIver, L.J.; Schwager, R.; Poon, T.W.; Ananthakrishnan, A.N.; Andrews, E.; Barron, G.; Lake, K.; et al. Dynamics of metatranscription in the inflammatory bowel disease gut microbiome. Nat. Microbiol. 2018, 3, 337-346. [CrossRef] [PubMed]

4. Bhattarai, Y.; Muniz Pedrogo, D.A.; Kashyap, P.C. Irritable bowel syndrome: A gut microbiota-related disorder? Am. J. Physiol. Gastrointest. Liver Physiol. 2017, 312, G52-G62. [CrossRef] 
5. Herndon, C.C.; Wang, Y.P.; Lu, C.L. Targeting the gut microbiota for the treatment of irritable bowel syndrome. Kaohsiung J. Med. Sci. 2019, 36, 160-170. [CrossRef] [PubMed]

6. Johnson, C.C.; Ownby, D.R. The infant gut bacterial microbiota and risk of pediatric asthma and allergic diseases. Transl. Res. 2017, 179, 60-70. [CrossRef] [PubMed]

7. Melli, L.C.; do Carmo-Rodrigues, M.S.; Araujo-Filho, H.B.; Sole, D.; de Morais, M.B. Intestinal microbiota and allergic diseases: A systematic review. Allergol. Immunopathol. 2016, 44, 177-188. [CrossRef] [PubMed]

8. Fujimura, K.E.; Lynch, S.V. Microbiota in allergy and asthma and the emerging relationship with the gut microbiome. Cell Host Microbe 2015, 17, 592-602. [CrossRef]

9. Cerdo, T.; Dieguez, E.; Campoy, C. Impact of gut microbiota on neurogenesis and neurological diseases during infancy. Curr. Opin. Pharmacol. 2020, 50, 33-37. [CrossRef] [PubMed]

10. Ma, Q.; Xing, C.; Long, W.; Wang, H.Y.; Liu, Q.; Wang, R.F. Impact of microbiota on central nervous system and neurological diseases: The gut-brain axis. J. Neuroinflamm. 2019, 16, 53. [CrossRef] [PubMed]

11. Ghaisas, S.; Maher, J.; Kanthasamy, A. Gut microbiome in health and disease: Linking the microbiome-gut-brain axis and environmental factors in the pathogenesis of systemic and neurodegenerative diseases. Pharmacol. Ther. 2016, 158, 52-62. [CrossRef] [PubMed]

12. Patterson, E.; Ryan, P.M.; Cryan, J.F.; Dinan, T.G.; Ross, R.P.; Fitzgerald, G.F.; Stanton, C. Gut microbiota, obesity and diabetes. Postgrad. Med. J. 2016, 92, 286-300. [CrossRef] [PubMed]

13. Sivamaruthi, B.S.; Kesika, P.; Suganthy, N.; Chaiyasut, C. A Review on Role of Microbiome in Obesity and Antiobesity Properties of Probiotic Supplements. Biomed. Res. Int. 2019, 2019, 3291367. [CrossRef] [PubMed]

14. Boulange, C.L.; Neves, A.L.; Chilloux, J.; Nicholson, J.K.; Dumas, M.E. Impact of the gut microbiota on inflammation, obesity, and metabolic disease. Genome Med. 2016, 8, 42. [CrossRef] [PubMed]

15. Jarbrink-Sehgal, E.; Andreasson, A. The gut microbiota and mental health in adults. Curr. Opin. Neurobiol. 2020, 62, 102-114. [CrossRef]

16. Lyte, M. Microbial endocrinology and the microbiota-gut-brain axis. Adv. Exp. Med. Biol. 2014, 817, 3-24.

17. Erny, D.; Hrabe de Angelis, A.L.; Jaitin, D.; Wieghofer, P.; Staszewski, O.; David, E.; Keren-Shaul, H.; Mahlakoiv, T.; Jakobshagen, K.; Buch, T.; et al. Host microbiota constantly control maturation and function of microglia in the CNS. Nat. Neurosci. 2015, 18, 965-977. [CrossRef] [PubMed]

18. Morais, L.H.; Schreiber, H.L.; Mazmanian, S.K. The gut microbiota-brain axis in behaviour and brain disorders. Nat. Rev. Microbiol. 2021, 19, 241-255. [CrossRef]

19. O'Mahony, S.M.; Clarke, G.; Borre, Y.E.; Dinan, T.G.; Cryan, J.F. Serotonin, tryptophan metabolism and the brain-gut-microbiome axis. Behav. Brain Res. 2015, 277, 32-48. [CrossRef] [PubMed]

20. Dinan, T.G.; Cryan, J.F. Gut instincts: Microbiota as a key regulator of brain development, ageing and neurodegeneration. J. Physiol. 2017, 595, 489. [CrossRef] [PubMed]

21. Kennedy, P.J.; Cryan, J.F.; Dinan, T.G.; Clarke, G. Kynurenine pathway metabolism and the microbiota-gut-brain axis. Neuropharmacology 2017, 112, 399-412. [CrossRef]

22. Lin, L.; Zhang, J. Role of intestinal microbiota and metabolites on gut homeostasis and human diseases. BMC Immunol. 2017, 18, 2. [CrossRef] [PubMed]

23. Rowland, I.; Gibson, G.; Heinken, A.; Scott, K.; Swann, J.; Thiele, I.; Tuohy, K. Gut microbiota functions: Metabolism of nutrients and other food components. Eur. J. Nutr. 2018, 57, 1-24. [CrossRef] [PubMed]

24. Rooks, M.G.; Garrett, W.S. Gut microbiota, metabolites and host immunity. Nat. Rev. Immunol. 2016, 16, 341-352. [CrossRef]

25. Noble, E.E.; Hsu, T.M.; Kanoski, S.E. Gut to Brain Dysbiosis: Mechanisms Linking Western Diet Consumption, the Microbiome, and Cognitive Impairment. Front. Behav. Neurosci. 2017, 11, 9. [CrossRef]

26. Mulak, A.; Bonaz, B. Brain-gut-microbiota axis in Parkinson's disease. World J. Gastroenterol. 2015, 21, 10609-10620. [CrossRef] [PubMed]

27. Friedland, R.P. Mechanisms of molecular mimicry involving the microbiota in neurodegeneration. J. Alzheimer's Dis. 2015, 45, 349-362. [CrossRef] [PubMed]

28. Cheng, J.; Palva, A.M.; de Vos, W.M.; Satokari, R. Contribution of the intestinal microbiota to human health: From birth to 100 years of age. Curr. Top. Microbiol. Immunol. 2013, 358, 323-346.

29. Claesson, M.J.; Cusack, S.; O’Sullivan, O.; Greene-Diniz, R.; de Weerd, H.; Flannery, E.; Marchesi, J.R.; Falush, D.; Dinan, T.; Fitzgerald, G.; et al. Composition, variability, and temporal stability of the intestinal microbiota of the elderly. Proc. Nat. Acad. Sci. USA 2011, 108 (Suppl. 1), 4586-4591. [CrossRef]

30. Sini, P.; Dang, T.B.C.; Fais, M.; Galioto, M.; Padedda, B.M.; Luglie, A.; Iaccarino, C.; Crosio, C. Cyanobacteria, Cyanotoxins, and Neurodegenerative Diseases: Dangerous Liaisons. Int. J. Mol. Sci. 2021, 22, 8726. [CrossRef] [PubMed]

31. Angelucci, F.; Cechova, K.; Amlerova, J.; Hort, J. Antibiotics, gut microbiota, and Alzheimer's disease. J. Neuroinflamm. 2019, 16, 108. [CrossRef] [PubMed]

32. Brandscheid, C.; Schuck, F.; Reinhardt, S.; Schafer, K.H.; Pietrzik, C.U.; Grimm, M.; Hartmann, T.; Schwiertz, A.; Endres, K. Altered Gut Microbiome Composition and Tryptic Activity of the 5xFAD Alzheimer's Mouse Model. J. Alzheimer's Dis. 2017, 56, 775-788. [CrossRef] [PubMed]

33. Harach, T.; Marungruang, N.; Duthilleul, N.; Cheatham, V.; Mc Coy, K.D.; Frisoni, G.; Neher, J.J.; Fak, F.; Jucker, M.; Lasser, T.; et al. Reduction of Abeta amyloid pathology in APPPS1 transgenic mice in the absence of gut microbiota. Sci. Rep. 2017, 7, 41802. [CrossRef] [PubMed] 
34. Vogt, N.M.; Kerby, R.L.; Dill-McFarland, K.A.; Harding, S.J.; Merluzzi, A.P.; Johnson, S.C.; Carlsson, C.M.; Asthana, S.; Zetterberg, H.; Blennow, K.; et al. Gut microbiome alterations in Alzheimer's disease. Sci. Rep. 2017, 7, 13537. [CrossRef] [PubMed]

35. Cattaneo, A.; Cattane, N.; Galluzzi, S.; Provasi, S.; Lopizzo, N.; Festari, C.; Ferrari, C.; Guerra, U.P.; Paghera, B.; Muscio, C.; et al. Association of brain amyloidosis with pro-inflammatory gut bacterial taxa and peripheral inflammation markers in cognitively impaired elderly. Neurobiol. Aging 2017, 49, 60-68. [CrossRef]

36. Liu, P.; Wu, L.; Peng, G.; Han, Y.; Tang, R.; Ge, J.; Zhang, L.; Jia, L.; Yue, S.; Zhou, K.; et al. Altered microbiomes distinguish Alzheimer's disease from amnestic mild cognitive impairment and health in a Chinese cohort. Brain Behav. Immun. 2019, 80, 633-643. [CrossRef]

37. Cummings, J.H.; Pomare, E.W.; Branch, W.J.; Naylor, C.P.; Macfarlane, G.T. Short chain fatty acids in human large intestine, portal, hepatic and venous blood. Gut 1987, 28, 1221-1227. [CrossRef]

38. Macfarlane, G.T.; Macfarlane, S. Bacteria, colonic fermentation, and gastrointestinal health. J. AOAC Int. 2012, 95, 50-60. [CrossRef]

39. Jiang, C.; Li, G.; Huang, P.; Liu, Z.; Zhao, B. The Gut Microbiota and Alzheimer's Disease. J. Alzheimer's Dis. 2017, 58, 1-15. [CrossRef]

40. Cerovic, M.; Forloni, G.; Balducci, C. Neuroinflammation and the Gut Microbiota: Possible Alternative Therapeutic Targets to Counteract Alzheimer's Disease? Front Aging Neurosci. 2019, 11, 284. [CrossRef]

41. Cassani, E.; Barichella, M.; Cancello, R.; Cavanna, F.; Iorio, L.; Cereda, E.; Bolliri, C.; Zampella Maria, P.; Bianchi, F.; Cestaro, B.; et al. Increased urinary indoxyl sulfate (indican): New insights into gut dysbiosis in Parkinson's disease. Parkinsonism Relat. Disord. 2015, 21, 389-393. [CrossRef]

42. Scheperjans, F.; Aho, V.; Pereira, P.A.; Koskinen, K.; Paulin, L.; Pekkonen, E.; Haapaniemi, E.; Kaakkola, S.; Eerola-Rautio, J.; Pohja, M.; et al. Gut microbiota are related to Parkinson's disease and clinical phenotype. Mov. Disord. 2015, 30, 350-358. [CrossRef] [PubMed]

43. Ohland, C.L.; Macnaughton, W.K. Probiotic bacteria and intestinal epithelial barrier function. Am. J. Physiol. Gastrointest. Liver Physiol. 2010, 298, G807. [CrossRef] [PubMed]

44. Hooper, L.V.; Wong, M.H.; Thelin, A.; Hansson, L.; Falk, P.G.; Gordon, J.I. Molecular analysis of commensal host-microbial relationships in the intestine. Science 2001, 291, 881-884. [CrossRef]

45. Hooper, L.V.; Stappenbeck, T.S.; Hong, C.V.; Gordon, J.I. Angiogenins: A new class of microbicidal proteins involved in innate immunity. Nat. Immunol. 2003, 4, 269-273. [CrossRef] [PubMed]

46. Sartor, R.B. Mechanisms of disease: Pathogenesis of Crohn's disease and ulcerative colitis. Nat. Clin. Pract. Gastroenterol. Hepatol. 2006, 3, 390-407. [CrossRef] [PubMed]

47. Anderson, R.C.; Cookson, A.L.; McNabb, W.C.; Park, Z.; McCann, M.J.; Kelly, W.J.; Roy, N.C. Lactobacillus plantarum MB452 enhances the function of the intestinal barrier by increasing the expression levels of genes involved in tight junction formation. BMC Microbiol. 2010, 10, 316. [CrossRef]

48. Hummel, S.; Veltman, K.; Cichon, C.; Sonnenborn, U.; Schmidt, M.A. Differential targeting of the E-Cadherin/ $\beta$-Catenin complex by gram-positive probiotic lactobacilli improves epithelial barrier function. Appl. Environ. Microbiol. 2012, 78, 1140-1147. [CrossRef] [PubMed]

49. Bruewer, M.; Samarin, S.; Nusrat, A. Inflammatory bowel disease and the apical junctional complex. Ann. N. Y. Acad. Sci. 2006, 1072, 242-252. [CrossRef]

50. Tanaka, M.; Toldi, J.; Vecsei, L. Exploring the Etiological Links behind Neurodegenerative Diseases: Inflammatory Cytokines and Bioactive Kynurenines. Int. J. Mol. Sci. 2020, 21, 2431. [CrossRef]

51. Mack, D.R.; Ahrne, S.; Hyde, L.; Wei, S.; Hollingsworth, M.A. Extracellular MUC3 mucin secretion follows adherence of Lactobacillus strains to intestinal epithelial cells in vitro. Gut 2003, 52, 827-833. [CrossRef] [PubMed]

52. Mattar, A.F.; Teitelbaum, D.H.; Drongowski, R.A.; Yongyi, F.; Harmon, C.M.; Coran, A.G. Probiotics up-regulate MUC-2 mucin gene expression in a Caco-2 cell-culture model. Pediatr. Surg. Int. 2002, 18, 586-590.

53. Kim, Y.; Kim, S.H.; Whang, K.Y.; Kim, Y.J.; Oh, S. Inhibition of Escherichia coli O157:H7 attachment by interactions between lactic acid bacteria and intestinal epithelial cells. J. Microbiol. Biotechnol. 2008, 18, 1278-1285. [PubMed]

54. Canny, G.O.; McCormick, B.A. Bacteria in the intestine, helpful residents or enemies from within? Infect. Immun. 2008, 76, 3360-3373. [CrossRef]

55. Ribet, D.; Cossart, P. How bacterial pathogens colonize their hosts and invade deeper tissues. Microbes Infect. 2015, 17, 173-183. [CrossRef] [PubMed]

56. Buffie, C.G.; Pamer, E.G. Microbiota-mediated colonization resistance against intestinal pathogens. Nat. Rev. Immunol. 2013, 13, 790-801. [CrossRef]

57. Bäumler, A.J.; Sperandio, V. Interactions between the microbiota and pathogenic bacteria in the gut. Nature 2016, 535, 85-93. [CrossRef]

58. Johnston, B.C.; Goldenberg, J.Z.; Vandvik, P.O.; Sun, X.; Guyatt, G.H. Probiotics for the prevention of pediatric antibiotic-associated diarrhea. Cochrane Database Syst. Rev. 2011, 11, CD004827.

59. Casburn-Jones, A.C.; Farthing, M.J. Management of infectious diarrhoea. Gut 2004, 53, 296-305. [CrossRef]

60. Clemente, J.C.; Ursell, L.K.; Parfrey, L.W.; Knight, R. The impact of the gut microbiota on human health: An integrative view. Cell 2012, 148, 1258-1270. [CrossRef]

61. Ashraf, R.; Shah, N.P. Immune system stimulation by probiotic microorganisms. Crit. Rev. Food Sci. Nutr. 2014, 54, 938-956. [CrossRef] 
62. Drago, L.; De Vecchi, E.; Gabrieli, A.; De Grandi, R.; Toscano, M. Immunomodulatory Effects of Lactobacillus salivarius LS01 and Bifidobacterium breve BR03, Alone and in Combination, on Peripheral Blood Mononuclear Cells of Allergic Asthmatics. Allergy Asthma Immunol. Res. 2015, 7, 409-413. [CrossRef]

63. Elian, S.D.; Souza, E.L.; Vieira, A.T.; Teixeira, M.M.; Arantes, R.M.; Nicoli, J.R.; Martins, F.S. Bifidobacterium longum subsp. infantis BB-02 attenuates acute murine experimental model of inflammatory bowel disease. Benef. Microbes 2015, 6, 277-286. [CrossRef]

64. Mileti, E.; Matteoli, G.; Iliev, I.D.; Rescigno, M. Comparison of the immunomodulatory properties of three probiotic strains of Lactobacilli using complex culture systems: Prediction for in vivo efficacy. PLoS ONE 2009, 4, e7056. [CrossRef] [PubMed]

65. Scaldaferri, F.; Gerardi, V.; Lopetuso, L.R.; Del Zompo, F.; Mangiola, F.; Boškoski, I.; Bruno, G.; Petito, V.; Laterza, L.; Cammarota, G.; et al. Gut microbial flora, prebiotics, and probiotics in IBD: Their current usage and utility. BioMed Res. Int. 2013, 2013, 435268. [CrossRef] [PubMed]

66. Bentley, R.; Meganathan, R. Biosynthesis of vitamin K (menaquinone) in bacteria. Microbiol. Rev. 1982, 46, 241-280. [CrossRef] [PubMed]

67. Wostmann, B.S. The germfree animal in nutritional studies. Annu. Rev. Nutr. 1981, 1, 257-279. [CrossRef]

68. Cotter, P.D.; Ross, R.P.; Hill, C. Bacteriocins-A viable alternative to antibiotics? Nat. Rev. Microbiol. 2013, 11, 95-105. [CrossRef]

69. Vonk, R.J.; Reckman, G.A.R.; Harmsen, H.J.M.; Priebe, M.G. Probiotics and Lactose Intolerance. Probiotics 2012, 7, $32-38$.

70. Frankel, W.L.; Zhang, W.; Singh, A.; Klurfeld, D.M.; Don, S.; Sakata, T.; Modlin, I.; Rombeau, J.L. Mediation of the trophic effects of short-chain fatty acids on the rat jejunum and colon. Gastroenterology 1994, 106, 375-380. [CrossRef]

71. Tanaka, M.; Torok, N.; Toth, F.; Szabo, A.; Vecsei, L. Co-Players in Chronic Pain: Neuroinflammation and the TryptophanKynurenine Metabolic Pathway. Biomedicines 2021, 9, 897. [CrossRef]

72. Tanaka, M.; Toth, F.; Polyak, H.; Szabo, A.; Mandi, Y.; Vecsei, L. Immune Influencers in Action: Metabolites and Enzymes of the Tryptophan-Kynurenine Metabolic Pathway. Biomedicines 2021, 9, 734. [CrossRef]

73. Le Floc'h, N.; Otten, W.; Merlot, E. Tryptophan metabolism, from nutrition to potential therapeutic applications. Amino Acids 2011, 41, 1195-1205. [CrossRef] [PubMed]

74. Stone, T.W.; Stoy, N.; Darlington, L.G. An expanding range of targets for kynurenine metabolites of tryptophan. Trends Pharmacol. Sci. 2013, 34, 136-143. [CrossRef]

75. van der Goot, A.T.; Nollen, E.A. Tryptophan metabolism: Entering the field of aging and age-related pathologies. Trends Mol. Med. 2013, 19, 336-344. [CrossRef] [PubMed]

76. Braidy, N.; Grant, R.; Adams, S.; Brew, B.J.; Guillemin, G.J. Mechanism for quinolinic acid cytotoxicity in human astrocytes and neurons. Neurotox. Res. 2009, 16, 77-86. [CrossRef] [PubMed]

77. Vamos, E.; Pardutz, A.; Klivenyi, P.; Toldi, J.; Vecsei, L. The role of kynurenines in disorders of the central nervous system: Possibilities for neuroprotection. J. Neurol. Sci. 2009, 283, 21-27. [CrossRef]

78. Schwarcz, R.; Bruno, J.P.; Muchowski, P.J.; Wu, H.Q. Kynurenines in the mammalian brain: When physiology meets pathology. Nat. Rev. Neurosci. 2012, 13, 465-477. [CrossRef]

79. Widner, B.; Leblhuber, F.; Walli, J.; Tilz, G.P.; Demel, U.; Fuchs, D. Tryptophan degradation and immune activation in Alzheimer's disease. J. Neural Transm. 2000, 107, 343-353. [CrossRef]

80. Clarke, G.; Grenham, S.; Scully, P.; Fitzgerald, P.; Moloney, R.D.; Shanahan, F.; Dinan, T.G.; Cryan, J.F. The microbiome-gut-brain axis during early life regulates the hippocampal serotonergic system in a sex-dependent manner. Mol. Psychiatry 2013, 18, 666-673. [CrossRef] [PubMed]

81. Wikoff, W.R.; Anfora, A.T.; Liu, J.; Schultz, P.G.; Lesley, S.A.; Peters, E.C.; Siuzdak, G. Metabolomics analysis reveals large effects of gut microflora on mammalian blood metabolites. Proc. Natl. Acad. Sci. USA 2009, 106, 3698-3703. [CrossRef]

82. Ting, K.K.; Brew, B.; Guillemin, G. The involvement of astrocytes and kynurenine pathway in Alzheimer's disease. Neurotox. Res. 2007, 12, 247-262. [CrossRef]

83. Ogawa, T.; Matson, W.R.; Beal, M.F.; Myers, R.H.; Bird, E.D.; Milbury, P.; Saso, S. Kynurenine pathway abnormalities in Parkinson's disease. Neurology 1992, 42, 1702-1706. [CrossRef] [PubMed]

84. Guidetti, P.; Luthi-Carter, R.E.; Augood, S.J.; Schwarcz, R. Neostriatal and cortical quinolinate levels are increased in early grade Huntington's disease. Neurobiol. Dis. 2004, 17, 455-461. [CrossRef] [PubMed]

85. Desbonnet, L.; Garrett, L.; Clarke, G.; Bienenstock, J.; Dinan, T.G. The probiotic Bifidobacteria infantis: An assessment of potential antidepressant properties in the rat. J. Psychiatr. Res. 2008, 43, 164-174. [CrossRef]

86. Cirrito, J.R.; Disabato, B.M.; Restivo, J.L.; Verges, D.K.; Goebel, W.D.; Sathyan, A.; Hayreh, D.; D’Angelo, G.; Benzinger, T.; Yoon, H.; et al. Serotonin signaling is associated with lower amyloid- $\beta$ levels and plaques in transgenic mice and humans. Proc. Natl. Acad. Sci. USA 2011, 108, 14968-14973. [CrossRef]

87. Cryan, J.F.; Dinan, T.G. Mind-altering microorganisms: The impact of the gut microbiota on brain and behaviour. Nat. Rev. Neurosci. 2012, 13, 701-712. [CrossRef] [PubMed]

88. Hamer, H.M.; Jonkers, D.; Venema, K.; Vanhoutvin, S.; Troost, F.J.; Brummer, R.J. Review article: The role of butyrate on colonic function. Aliment. Pharmacol. Ther. 2008, 27, 104-119. [CrossRef]

89. Tagliabue, A.; Elli, M. The role of gut microbiota in human obesity: Recent findings and future perspectives. Nutr. Metab. Cardiovasc. Dis. 2013, 23, 160-168. [CrossRef]

90. den Besten, G.; van Eunen, K.; Groen, A.K.; Venema, K.; Reijngoud, D.J.; Bakker, B.M. The role of short-chain fatty acids in the interplay between diet, gut microbiota, and host energy metabolism. J. Lipid Res. 2013, 54, 2325-2340. [CrossRef] [PubMed] 
91. Gao, Z.; Yin, J.; Zhang, J.; Ward, R.E.; Martin, R.J.; Lefevre, M.; Cefalu, W.T.; Ye, J. Butyrate improves insulin sensitivity and increases energy expenditure in mice. Diabetes 2009, 58, 1509-1517. [CrossRef] [PubMed]

92. Fushimi, T.; Suruga, K.; Oshima, Y.; Fukiharu, M.; Tsukamoto, Y.; Goda, T. Dietary acetic acid reduces serum cholesterol and triacylglycerols in rats fed a cholesterol-rich diet. Br. J. Nutr. 2006, 95, 916-924. [CrossRef]

93. Todesco, T.; Rao, A.V.; Bosello, O.; Jenkins, D.J. Propionate lowers blood glucose and alters lipid metabolism in healthy subjects. Am. J. Clin. Nutr. 1991, 54, 860-865. [CrossRef] [PubMed]

94. Sampson, T.R.; Debelius, J.W.; Thron, T.; Janssen, S.; Shastri, G.G.; Ilhan, Z.E.; Challis, C.; Schretter, C.E.; Rocha, S.; Gradinaru, V.; et al. Gut Microbiota Regulate Motor Deficits and Neuroinflammation in a Model of Parkinson's Disease. Cell 2016, 167, 1469-1480.e12. [CrossRef]

95. Sadler, R.; Cramer, J.V.; Heindl, S.; Kostidis, S.; Betz, D.; Zuurbier, K.R.; Northoff, B.H.; Heijink, M.; Goldberg, M.P.; Plautz, E.J.; et al. Short-Chain Fatty Acids Improve Poststroke Recovery via Immunological Mechanisms. J. Neurosci. 2020, 40, 1162-1173. [CrossRef]

96. Frost, G.; Sleeth, M.L.; Sahuri-Arisoylu, M.; Lizarbe, B.; Cerdan, S.; Brody, L.; Anastasovska, J.; Ghourab, S.; Hankir, M.; Zhang, S.; et al. The short-chain fatty acid acetate reduces appetite via a central homeostatic mechanism. Nat. Commun. 2014, 5, 3611. [CrossRef] [PubMed]

97. Wyss, M.T.; Magistretti, P.J.; Buck, A.; Weber, B. Labeled acetate as a marker of astrocytic metabolism. J. Cereb. Blood Flow Metab. 2011, 31, 1668-1674. [CrossRef]

98. Bourassa, M.W.; Alim, I.; Bultman, S.J.; Ratan, R.R. Butyrate, neuroepigenetics and the gut microbiome: Can a high fiber diet improve brain health? Neurosci. Lett. 2016, 625, 56-63. [CrossRef]

99. Kuwahara, A. Contributions of colonic short-chain Fatty Acid receptors in energy homeostasis. Front. Endocrinol. 2014, 5, 144. [CrossRef]

100. Naddafi, F.; Mirshafiey, A. The neglected role of histamine in Alzheimer's disease. Am. J. Alzheimers Dis. Other Demen. 2013, 28, 327-336. [CrossRef]

101. del Rio, R.; Noubade, R.; Saligrama, N.; Wall, E.H.; Krementsov, D.N.; Poynter, M.E.; Zachary, J.F.; Thurmond, R.L.; Teuscher, C. Histamine $\mathrm{H} 4$ receptor optimizes $\mathrm{T}$ regulatory cell frequency and facilitates anti-inflammatory responses within the central nervous system. J. Immunol. 2012, 188, 541-547. [CrossRef]

102. Landete, J.M.; De las Rivas, B.; Marcobal, A.; Muñoz, R. Updated molecular knowledge about histamine biosynthesis by bacteria. Crit. Rev. Food Sci. Nutr. 2008, 48, 697-714. [CrossRef] [PubMed]

103. Thomas, C.M.; Hong, T.; van Pijkeren, J.P.; Hemarajata, P.; Trinh, D.V.; Hu, W.; Britton, R.A.; Kalkum, M.; Versalovic, J. Histamine derived from probiotic Lactobacillus reuteri suppresses TNF via modulation of PKA and ERK signaling. PLoS ONE 2012, 7, e31951. [CrossRef]

104. Alvarez, X.A.; Franco, A.; Fernández-Novoa, L.; Cacabelos, R. Blood levels of histamine, IL-1 beta, and TNF-alpha in patients with mild to moderate Alzheimer disease. Mol. Chem. Neuropathol. 1996, 29, 237-252. [CrossRef]

105. Stasiak, A.; Mussur, M.; Unzeta, M.; Lazewska, D.; Kiec-Kononowicz, K.; Fogel, W.A. The central histamine level in rat model of vascular dementia. J. Physiol. Pharmacol. 2011, 62, 549-558.

106. Chen, L.; Xing, T.; Wang, M.; Miao, Y.; Tang, M.; Chen, J.; Li, G.; Ruan, D.Y. Local infusion of ghrelin enhanced hippocampal synaptic plasticity and spatial memory through activation of phosphoinositide 3-kinase in the dentate gyrus of adult rats. Eur. J. Neurosci. 2011, 33, 266-275. [CrossRef]

107. Gahete, M.D.; Córdoba-Chacón, J.; Kineman, R.D.; Luque, R.M.; Castaño, J.P. Role of ghrelin system in neuroprotection and cognitive functions: Implications in Alzheimer's disease. Peptides 2011, 32, 2225-2228. [CrossRef] [PubMed]

108. Dos Santos, V.V.; Rodrigues, A.L.; De Lima, T.C.; de Barioglio, S.R.; Raisman-Vozari, R.; Prediger, R.D. Ghrelin as a neuroprotective and palliative agent in Alzheimer's and Parkinson's disease. Curr. Pharm. Des. 2013, 19, 6773-6790. [CrossRef]

109. Steinert, R.E.; Feinle-Bisset, C.; Asarian, L.; Horowitz, M.; Beglinger, C.; Geary, N. Ghrelin, CCK, GLP-1, and PYY(3-36): Secretory Controls and Physiological Roles in Eating and Glycemia in Health, Obesity, and After RYGB. Physiol. Rev. 2017, 97, 411-463. [CrossRef] [PubMed]

110. Fallucca, F.; Porrata, C.; Fallucca, S.; Pianesi, M. Influence of diet on gut microbiota, inflammation and type 2 diabetes mellitus. First experience with macrobiotic Ma-Pi 2 diet. Rev. Mar. Cost. 2014, 30 (Suppl. 1), 48-54. [CrossRef] [PubMed]

111. Forsythe, P.; Kunze, W.A.; Bienenstock, J. On communication between gut microbes and the brain. Curr. Opin. Gastroenterol. 2012, 28, 557-562. [CrossRef]

112. Lyte, M. Microbial endocrinology: Host-microbiota neuroendocrine interactions influencing brain and behavior. Gut Microbes 2014, 5, 381-389. [CrossRef] [PubMed]

113. Barrett, E.; Ross, R.P.; O’Toole, P.W.; Fitzgerald, G.F.; Stanton, C. $\gamma$-Aminobutyric acid production by culturable bacteria from the human intestine. J. Appl. Microbiol. 2012, 113, 411-417. [CrossRef]

114. Hanke, M.L.; Kielian, T. Toll-like receptors in health and disease in the brain: Mechanisms and therapeutic potential. Clin. Sci. 2011, 121, 367-387. [CrossRef] [PubMed]

115. Akira, S.; Uematsu, S.; Takeuchi, O. Pathogen recognition and innate immunity. Cell 2006, 124, 783-801. [CrossRef]

116. Sherwin, E.; Sandhu, K.V.; Dinan, T.G.; Cryan, J.F. May the Force Be with You: The Light and Dark Sides of the Microbiota-GutBrain Axis in Neuropsychiatry. CNS Drugs 2016, 30, 1019-1041. [CrossRef] 
117. Gonzalez-Sanmiguel, J.; Schuh, C.; Munoz-Montesino, C.; Contreras-Kallens, P.; Aguayo, L.G.; Aguayo, S. Complex Interaction between Resident Microbiota and Misfolded Proteins: Role in Neuroinflammation and Neurodegeneration. Cells 2020, 9, 2476. [CrossRef] [PubMed]

118. Arentsen, T.; Qian, Y.; Gkotzis, S.; Femenia, T.; Wang, T.; Udekwu, K.; Forssberg, H.; Diaz Heijtz, R. The bacterial peptidoglycansensing molecule Pglyrp2 modulates brain development and behavior. Mol. Psychiatry 2017, 22, 257-266. [CrossRef]

119. Zhao, J.; Bi, W.; Xiao, S.; Lan, X.; Cheng, X.; Zhang, J.; Lu, D.; Wei, W.; Wang, Y.; Li, H.; et al. Neuroinflammation induced by lipopolysaccharide causes cognitive impairment in mice. Sci. Rep. 2019, 9, 5790. [CrossRef]

120. Romero, E.; Ali, C.; Molina-Holgado, E.; Castellano, B.; Guaza, C.; Borrell, J. Neurobehavioral and immunological consequences of prenatal immune activation in rats. Influence of antipsychotics. Neuropsychopharmacology 2007, 32, 1791-1804. [CrossRef]

121. Izvolskaia, M.; Sharova, V.; Zakharova, L. Prenatal Programming of Neuroendocrine System Development by Lipopolysaccharide: Long-Term Effects. Int. J. Mol. Sci. 2018, 19, 3695. [CrossRef]

122. Sgritta, M.; Dooling, S.W.; Buffington, S.A.; Momin, E.N.; Francis, M.B.; Britton, R.A.; Costa-Mattioli, M. Mechanisms Underlying Microbial-Mediated Changes in Social Behavior in Mouse Models of Autism Spectrum Disorder. Neuron 2019, 101, 246-259.e6. [CrossRef] [PubMed]

123. Needham, B.D.; Kaddurah-Daouk, R.; Mazmanian, S.K. Gut microbial molecules in behavioural and neurodegenerative conditions. Nat. Rev. Neurosci. 2020, 21,717-731. [CrossRef]

124. Goehler, L.E.; Park, S.M.; Opitz, N.; Lyte, M.; Gaykema, R.P. Campylobacter jejuni infection increases anxiety-like behavior in the holeboard: Possible anatomical substrates for viscerosensory modulation of exploratory behavior. Brain Behav. Immun. 2008, 22, 354-366. [CrossRef] [PubMed]

125. Lyte, M.; Li, W.; Opitz, N.; Gaykema, R.P.; Goehler, L.E. Induction of anxiety-like behavior in mice during the initial stages of infection with the agent of murine colonic hyperplasia Citrobacter rodentium. Physiol. Behav. 2006, 89, 350-357. [CrossRef]

126. Bercik, P.; Park, A.J.; Sinclair, D.; Khoshdel, A.; Lu, J.; Huang, X.; Deng, Y.; Blennerhassett, P.A.; Fahnestock, M.; Moine, D.; et al. The anxiolytic effect of Bifidobacterium longum NCC3001 involves vagal pathways for gut-brain communication. Neurogastroenterol. Motil. 2011, 23, 1132-1139. [CrossRef] [PubMed]

127. Goehler, L.E.; Gaykema, R.P.; Opitz, N.; Reddaway, R.; Badr, N.; Lyte, M. Activation in vagal afferents and central autonomic pathways: Early responses to intestinal infection with Campylobacter jejuni. Brain Behav. Immun. 2005, 19, 334-344. [CrossRef]

128. Fuller, R. Probiotics in human medicine. Gut 1991, 32, 439. [CrossRef] [PubMed]

129. Wilson, K.H.; Perini, F. Role of competition for nutrients in suppression of Clostridium difficile by the colonic microflora. Infect. Immun. 1988, 56, 2610. [CrossRef] [PubMed]

130. Dando, S.J.; Mackay-Sim, A.; Norton, R.; Currie, B.J.; St John, J.A.; Ekberg, J.A.; Batzloff, M.; Ulett, G.C.; Beacham, I.R. Pathogens penetrating the central nervous system: Infection pathways and the cellular and molecular mechanisms of invasion. Clin. Microbiol. Rev. 2014, 27, 691. [CrossRef] [PubMed]

131. Branton, W.G.; Lu, J.Q.; Surette, M.G.; Holt, R.A.; Lind, J.; Laman, J.D.; Power, C. Brain microbiota disruption within inflammatory demyelinating lesions in multiple sclerosis. Sci. Rep. 2016, 6, 37344. [CrossRef]

132. Frohman, E.M.; Racke, M.K.; Raine, C.S. Multiple sclerosis-the plaque and its pathogenesis. N. Engl. J. Med. 2006, 354, 942-955. [CrossRef] [PubMed]

133. Franciotti, R.; Pignatelli, P.; Carrarini, C.; Romei, F.M.; Mastrippolito, M.; Gentile, A.; Mancinelli, R.; Fulle, S.; Piattelli, A.; Onofrj, M.; et al. Exploring the Connection between Porphyromonas gingivalis and Neurodegenerative Diseases: A Pilot Quantitative Study on the Bacterium Abundance in Oral Cavity and the amount of Antibodies in Serum. Biomolecules 2021, 11, 845. [CrossRef]

134. Dominy, S.S.; Lynch, C.; Ermini, F.; Benedyk, M.; Marczyk, A.; Konradi, A.; Nguyen, M.; Haditsch, U.; Raha, D.; Griffin, C.; et al. Porphyromonas gingivalis in Alzheimer's disease brains: Evidence for disease causation and treatment with small-molecule inhibitors. Sci. Adv. 2019, 5, eaau3333. [CrossRef]

135. Servick, K. Do gut bacteria make a second home in our brains? Science 2018, 10, 92. [CrossRef]

136. Abuaish, S.; Al-Otaibi, N.M.; Abujamel, T.S.; Alzahrani, S.A.; Alotaibi, S.M.; AlShawakir, Y.A.; Aabed, K.; El-Ansary, A. Fecal Transplant and Bifidobacterium Treatments Modulate Gut Clostridium Bacteria and Rescue Social Impairment and Hippocampal BDNF Expression in a Rodent Model of Autism. Brain Sci. 2021, 11, 1038. [CrossRef]

137. Yang, X.; Yu, D.; Xue, L.; Li, H.; Du, J. Probiotics modulate the microbiota-gut-brain axis and improve memory deficits in aged SAMP8 mice. Acta Pharm. Sin. B 2020, 10, 475. [CrossRef] [PubMed]

138. Athari Nik Azm, S.; Djazayeri, A.; Safa, M.; Azami, K.; Ahmadvand, B.; Sabbaghziarani, F.; Sharifzadeh, M.; Vafa, M. Lactobacilli and bifidobacteria ameliorate memory and learning deficits and oxidative stress in beta-amyloid (1-42) injected rats. Appl. Physiol. Nutr. Metab. 2018, 43, 718. [CrossRef]

139. Bonfili, L.; Cecarini, V.; Berardi, S.; Scarpona, S.; Suchodolski, J.S.; Nasuti, C.; Fiorini, D.; Boarelli, M.C.; Rossi, G.; Eleuteri, A.M. Microbiota modulation counteracts Alzheimer's disease progression influencing neuronal proteolysis and gut hormones plasma levels. Sci. Rep. 2017, 7, 2426. [CrossRef]

140. Mohammadi, G.; Dargahi, L.; Peymani, A.; Mirzanejad, Y.; Alizadeh, S.A.; Naserpour, T.; Nassiri-Asl, M. The Effects of Probiotic Formulation Pretreatment (Lactobacillus helveticus R0052 and Bifidobacterium longum R0175) on a Lipopolysaccharide Rat Model. J. Am. Coll. Nutr. 2019, 38, 209-217. [CrossRef] [PubMed] 
141. Mohammadi, G.; Dargahi, L.; Naserpour, T.; Mirzanejad, Y.; Alizadeh, S.A.; Peymani, A.; Nassiri-Asl, M. Probiotic mixture of Lactobacillus helveticus R0052 and Bifidobacterium longum R0175 attenuates hippocampal apoptosis induced by lipopolysaccharide in rats. Int. Microbiol. 2019, 22, 317. [CrossRef] [PubMed]

142. Kobayashi, Y.; Sugahara, H.; Shimada, K.; Mitsuyama, E.; Kuhara, T.; Yasuoka, A.; Kondo, T.; Abe, K.; Xiao, J.Z. Therapeutic potential of Bifidobacterium breve strain A1 for preventing cognitive impairment in Alzheimer's disease. Sci. Rep. 2017, 7, 13510. [CrossRef]

143. Nimgampalle, M.; Kuna, Y. Anti-Alzheimer Properties of Probiotic, Lactobacillus plantarum MTCC 1325 in Alzheimer's Disease induced Albino Rats. J. Clin. Diagn. Res. 2017, 11, KC01-KC05. [CrossRef] [PubMed]

144. Wang, T.; Hu, X.; Liang, S.; Li, W.; Wu, X.; Wang, L.; Jin, F. Lactobacillus fermentum NS9 restores the antibiotic induced physiological and psychological abnormalities in rats. Benef. Microbes 2015, 6, 707-717. [CrossRef]

145. Liang, S.; Wang, T.; Hu, X.; Luo, J.; Li, W.; Wu, X.; Duan, Y.; Jin, F. Administration of Lactobacillus helveticus NS8 improves behavioral, cognitive, and biochemical aberrations caused by chronic restraint stress. Neuroscience 2015, 310, 561-577. [CrossRef] [PubMed]

146. Abraham, D.; Feher, J.; Scuderi, G.L.; Szabo, D.; Dobolyi, A.; Cservenak, M.; Juhasz, J.; Ligeti, B.; Pongor, S.; Gomez-Cabrera, M.C.; et al. Exercise and probiotics attenuate the development of Alzheimer's disease in transgenic mice: Role of microbiome. Exp. Gerontol. 2019, 115, 122-131. [CrossRef]

147. Zhang, Y.G.; Wu, S.; Yi, J.; Xia, Y.; Jin, D.; Zhou, J.; Sun, J. Target Intestinal Microbiota to Alleviate Disease Progression in Amyotrophic Lateral Sclerosis. Clin. Ther. 2017, 39, 322-336. [CrossRef] [PubMed]

148. Fijan, S. Microorganisms with claimed probiotic properties: An overview of recent literature. Int. J. Environ. Res. Public Health 2014, 11, 4745-4767. [CrossRef] [PubMed]

149. Akbari, E.; Asemi, Z.; Daneshvar Kakhaki, R.; Bahmani, F.; Kouchaki, E.; Tamtaji, O.R.; Hamidi, G.A.; Salami, M. Effect of Probiotic Supplementation on Cognitive Function and Metabolic Status in Alzheimer's Disease: A Randomized, Double-Blind and Controlled Trial. Front. Aging Neurosci. 2016, 8, 256. [CrossRef] [PubMed]

150. Agahi, A.; Hamidi, G.A.; Daneshvar, R.; Hamdieh, M.; Soheili, M.; Alinaghipour, A.; Esmaeili Taba, S.M.; Salami, M. Does Severity of Alzheimer's Disease Contribute to Its Responsiveness to Modifying Gut Microbiota? A Double Blind Clinical Trial. Front. Neurol. 2018, 9, 662. [CrossRef]

151. Kobayashi, Y.; Kuhara, T.; Oki, M.; Xiao, J.Z. Effects of Bifidobacterium breve A1 on the cognitive function of older adults with memory complaints: A randomised, double-blind, placebo-controlled trial. Benef. Microbes. 2019, 10, 511-520. [CrossRef]

152. Barichella, M.; Pacchetti, C.; Bolliri, C.; Cassani, E.; Iorio, L.; Pusani, C.; Pinelli, G.; Privitera, G.; Cesari, I.; Faierman, S.A.; et al. Probiotics and prebiotic fiber for constipation associated with Parkinson disease: An RCT. Neurology 2016, 87, 1274-1280. [CrossRef]

153. Luo, J.; Wang, T.; Liang, S.; Hu, X.; Li, W.; Jin, F. Ingestion of Lactobacillus strain reduces anxiety and improves cognitive function in the hyperammonemia rat. Sci. China Life Sci. 2014, 57, 327-335. [CrossRef] [PubMed]

154. Marin, I.A.; Goertz, J.E.; Ren, T.; Rich, S.S.; Onengut-Gumuscu, S.; Farber, E.; Wu, M.; Overall, C.C.; Kipnis, J.; Gaultier, A. Microbiota alteration is associated with the development of stress-induced despair behavior. Sci. Rep. 2017, 7, 43859. [CrossRef]

155. Srivastav, S.; Neupane, S.; Bhurtel, S.; Katila, N.; Maharjan, S.; Choi, H.; Hong, J.T.; Choi, D.Y. Probiotics mixture increases butyrate, and subsequently rescues the nigral dopaminergic neurons from MPTP and rotenone-induced neurotoxicity. J. Nutr. Biochem. 2019, 69, 73. [CrossRef] [PubMed]

156. Hwang, Y.H.; Park, S.; Paik, J.W.; Chae, S.W.; Kim, D.H.; Jeong, D.G.; Ha, E.; Kim, M.; Hong, G.; Park, S.H.; et al. Efficacy and Safety of Lactobacillus plantarum C29-Fermented Soybean (DW2009) in Individuals with Mild Cognitive Impairment: A 12-Week, Multi-Center, Randomized, Double-Blind, Placebo-Controlled Clinical Trial. Nutrients 2019, 11, 305. [CrossRef]

157. Staley, C.; Khoruts, A.; Sadowsky, M.J. Contemporary Applications of Fecal Microbiota Transplantation to Treat Intestinal Diseases in Humans. Arch. Med. Res. 2017, 48, 766-773. [CrossRef]

158. Parker, A.; Fonseca, S.; Carding, S.R. Gut microbes and metabolites as modulators of blood-brain barrier integrity and brain health. Gut Microbes 2020, 11, 135-157. [CrossRef]

159. Gulati, M.; Singh, S.K.; Corrie, L.; Kaur, I.P.; Chandwani, L. Delivery routes for faecal microbiota transplants: Available, anticipated and aspired. Pharmacol. Res. 2020, 159, 104954. [CrossRef] [PubMed]

160. Dodiya, H.B.; Kuntz, T.; Shaik, S.M.; Baufeld, C.; Leibowitz, J.; Zhang, X.; Gottel, N.; Zhang, X.; Butovsky, O.; Gilbert, J.A.; et al. Sex-specific effects of microbiome perturbations on cerebral Abeta amyloidosis and microglia phenotypes. J. Exp. Med. 2019, 216, 1542-1560. [CrossRef] [PubMed]

161. Fujii, Y.; Nguyen, T.T.T.; Fujimura, Y.; Kameya, N.; Nakamura, S.; Arakawa, K.; Morita, H. Fecal metabolite of a gnotobiotic mouse transplanted with gut microbiota from a patient with Alzheimer's disease. Biosci. Biotechnol. Biochem. 2019, 83, 2144-2152. [CrossRef] [PubMed]

162. Woodworth, M.H.; Carpentieri, C.; Sitchenko, K.L.; Kraft, C.S. Challenges in fecal donor selection and screening for fecal microbiota transplantation: A review. Gut Microbes 2017, 8, 225-237. [CrossRef] [PubMed] 